\title{
Antibacterial Surface Coating for Bone Scaffolds Based on the Dark Catalytic Effect of Titanium Dioxide
}

\author{
David Wiedmer ${ }^{\mathrm{a}}$, Chen Cui ${ }^{\mathrm{a}}$, Florian Weber $^{\mathrm{a}}$, Fernanda C. Petersen ${ }^{\mathrm{b}}$, Hanna Tiainen ${ }^{\mathrm{a}, *}$ \\ ${ }^{a}$ Department of Biomaterials, Institute for Clinical Dentistry, University of Oslo, Norway \\ ${ }^{b}$ Department of Oral Biology, Faculty of Dentistry, University of Oslo, Norway
}

*Corresponding author

Tel.: +47-22852354

Email: hanna.tiainen@odont.uio.no

PO Box 1109 Blindern

0317 Oslo

Norway

Keywords: Titanium dioxide, porous scaffold, antibacterial coating, dark catalysis, sol-gel coating, $\mathrm{H}_{2} \mathrm{O}_{2}$ decomposition 


\section{Abstract}

Biomaterials which promote tissue integration and resist microbial colonisation are required in bone tissue engineering to prevent biomaterial-associated infections. Surface modification of established materials for bone tissue engineering, such as $\mathrm{TiO}_{2}$, have emerged as promising antiinfective strategies. Interestingly, the antibacterial activity of $\mathrm{TiO}_{2}$ in the form of particles can be enhanced by combining it with $\mathrm{H}_{2} \mathrm{O}_{2}$, even in the absence of irradiation. However, it remains unknown whether $\mathrm{TiO}_{2}$ surfaces elicit a similar effect. In this study, the antibacterial effect of porous $\mathrm{TiO}_{2}$ scaffolds generated by the catalytic decomposition of $\mathrm{H}_{2} \mathrm{O}_{2}$ in the absence of light (dark catalysis) was investigated. Porous ceramic foams were fabricated and sol-gel coated for high catalytic activity. Degradation of methylene blue in the presence of $3 \% \mathrm{H}_{2} \mathrm{O}_{2}$ increased by $80 \%$ for the sol-gel coated surfaces. The degradation kinetics indicate that intermediate free radicals that form at the liquid- $\mathrm{TiO}_{2}$ interface are responsible for the oxidative behaviour of the surface. $\mathrm{TiO}_{2}$ surfaces were further pre-treated with $30 \% \mathrm{H}_{2} \mathrm{O}_{2}$ for prolonged oxidative behaviour. The biological response towards such surfaces was assessed in vitro. S. epidermidis biofilms formed on modified surfaces showed reduced viability compared to non-modified surfaces. Further, the same surface modification showed no cytotoxic effects on MC3T3 pre-osteoblasts. However, the results from the conducted genotoxicity assay were inconclusive and further studies are needed to exclude ROSmediated DNA damage. To conclude, this study provides evidence that a simple surface modification based on the dark catalytic effect of $\mathrm{TiO}_{2}$ can be used to create antibacterial surface properties for ceramic bone scaffolds. 


\section{Introduction}

The therapy of non-healing skeletal defects generally requires the support of a three-dimensional framework to fill the defect volume and guide bone repair. ${ }^{1}$ Currently, the gold standard for the surgical treatment of such defects is the augmentation of missing tissue with bone transplants (autogeneous, allogeneous or xenogeneous). The use of these bone transplants is limited by the scarcity of donor tissue, immunogenic reactions or pathogen transfer. ${ }^{2}$ Ceramic bone graft substitutes may overcome these shortcomings and several scaffold-based treatments have shown to result in the development of vascularised bone in vivo. ${ }^{3-5}$

However, the success of synthetic scaffolds in bone restauration may be jeopardised by the occurrence of biomaterial-associated infections (BAI). ${ }^{6}$ The infection incidence for orthopaedic devices is only $0.5 \%-5 \%$ over the lifetime of the implant but often results in complicated revision surgeries and high economic consequences. ${ }^{7}$ Peri- and postoperative contamination with Grampositive aerobes, particularly staphylococci, have been identified as the major cause for BAI in orthopaedics. ${ }^{7-8}$ The initial contamination is defined by the attachment of planktonic bacteria onto the biomaterial surface and the subsequent formation of a bacterial biofilm. Biofilms are characterised by a three-dimensional structure of micro-organisms in a self-produced, extracellular polymeric substance (EPS). ${ }^{9}$ Pathogens which are incorporated in protective EPS show low metabolic activity and are generally less susceptible to host immune response or antibiotic therapy. ${ }^{10}$ Therefore, many surface modifications under development aim at the prevention of biofilm formation by creating an unfavourable environment for initial microbial adhesion. ${ }^{11}$

Commonly used scaffold materials in bone repair, such as ceramic calcium phosphates and various polymers, lack intrinsic antimicrobial properties and need to be functionalised for antimicrobial activity. Nonadhesive surfaces by e.g. hydrophilic polymer ${ }^{12}$ or polymer brush coatings ${ }^{13}$ are generally excluded for applications which require tissue integration. Coatings which release antimicrobial molecules, such as silver ${ }^{14}$ or antibiotics, ${ }^{15}$ or kill upon direct contact with bacteria, e.g. immobilised antimicrobial peptides, ${ }^{16}$ have shown high antibacterial activity against several pathogens in vitro. However, concerns remain regarding impaired host cell adhesion or cytotoxic effects of the coatings ${ }^{17-18}$ and the development of resistant microbes. ${ }^{19}$ Therefore, multifunctional coatings that combine antimicrobial activity and tissue integration have been suggested as the most promising candidates to fight BAI. ${ }^{6}$ 
Titanium dioxide $\left(\mathrm{TiO}_{2}\right)$ is a well-established scaffold material in bone repair with excellent biocompatibility and good osteoconductive properties. ${ }^{5,}{ }^{20}$ Highly porous $\mathrm{TiO}_{2}$ scaffolds with mechanical properties in the range of cancellous bone have been fabricated by the polymer sponge method. ${ }^{21}$ The good mechanical stability of these scaffolds is related to high sintering temperature applied which is accompanied by the phase transformation from anatase to rutile. ${ }^{22}$ Contrary to most other biomaterials, $\mathrm{TiO}_{2}$ possesses intrinsic antimicrobial activity due to its photocatalytic properties. ${ }^{23}$ In photocatalysis, strongly bactericidal reactive oxygen species (ROS) are formed under the irradiation of the ceramic surface with UV light. Today, $\mathrm{TiO}_{2}$ photocatalysis is used in water and air purification applications, while the potential as antimicrobial strategy in tissue integrating applications is often limited due to the dependency on UV irradiation. ${ }^{24-25}$ However, it has recently been shown that ROS can be formed in the absence of light during the catalytic decomposition of hydrogen peroxide $\left(\mathrm{H}_{2} \mathrm{O}_{2}\right)$ on $\mathrm{TiO}_{2}$ particles. ${ }^{26}$ The catalytic reaction was favoured on anatase and the superoxide anion $\left(\mathrm{O}_{2}^{-\bullet}\right)$ was shown to be the predominant radical species. ${ }^{26-27} \mathrm{O}_{2}{ }^{-\bullet}$ is highly toxic to a broad spectrum of pathogens and promising results for the antibacterial effect of $\mathrm{TiO}_{2}-\mathrm{H}_{2} \mathrm{O}_{2}$ suspensions in vitro have been reported. ${ }^{28-29}$ Further, it has been suggested that $\mathrm{O}_{2}{ }^{-\bullet}$ can be stabilised on metal oxide surfaces with prolonged oxidative behaviour. ${ }^{30-}$ 31 Therefore, $\mathrm{TiO}_{2}$ dark catalysis is an interesting approach in the search for antimicrobial surfaces. So far, the dark catalytic behaviour has only been shown for $\mathrm{TiO}_{2}$ particle suspensions. The aim of this study is to investigate the decomposition of $\mathrm{H}_{2} \mathrm{O}_{2}$ on porous $\mathrm{TiO}_{2}$ scaffolds. A thin film coating is applied and characterised in order to change the surface crystal structure of the scaffolds from rutile to anatase. The oxidative behaviour is assessed by the degradation of the model dye methylene blue (MB). Further, the biological response towards oxidative $\mathrm{TiO}_{2}$ surfaces is assessed against a S. epidermidis biofilm model and potential cyto- and genotoxic effects on the murine osteoblastic cell line MC3T3 are evaluated.

\section{Experimental section}

\subsection{Sample preparation}

Porous $\mathrm{TiO}_{2}$ scaffolds were fabricated as described by Tiainen et al. ${ }^{32}$ In short, commercial $\mathrm{TiO}_{2}$ powder (Kronos 1171, Kronos International, Leverkusen, Germany) was used to produce a shear- 
thinning ceramic slurry. Cylindrical polyurethane foams $(\varnothing=10 \mathrm{~mm})$ were infiltrated with the $\mathrm{TiO}_{2}$ slurry and a custom-made rolling machine was used to remove excess slurry. Samples were dried at room temperature (RT) for $24 \mathrm{~h}$ before a two-stage heat treatment was applied. First, samples were heated to $1100^{\circ} \mathrm{C}$ at $0.5 \mathrm{~K} \mathrm{~min}^{-1}$ and kept at this temperature for $1 \mathrm{~h}$ to burn out the polymer template (HTC-08/16, Nabertherm GmbH, Bremen, Germany). The green bodies were then heated to $1500^{\circ} \mathrm{C}$ at $3 \mathrm{~K} \mathrm{~min}^{-1}$ and sintered for $20 \mathrm{~h}$ before cooling down to RT at $5 \mathrm{~K} \mathrm{~min}^{-1}$. $\mathrm{TiO}_{2}$ discs $(\varnothing=14.6 \mathrm{~mm})$ were fabricated to represent the surface of scaffolds where analytical methods were not applicable to the porous 3D structure (topographical analysis, in vitro studies). Discs were prepared by pressing $\mathrm{TiO}_{2}$ powder in a mould using a hydraulic press at $20 \mathrm{kN}$. The heat treatment of discs and scaffolds was identical. In addition to $\mathrm{TiO}_{2}$ discs, silicon wafers ( $\mathrm{Si}$ (100), Sigma Aldrich, St. Louis Missouri, USA) were used as a coating substrate to determine the thickness and crystal structure of the coating.

\subsection{Surface modification}

$\mathrm{TiO}_{2}$ scaffolds and discs were modified by sol-gel dip-coating as previously described. ${ }^{33} \mathrm{~A}$ precursor sol was prepared by dissolving $6.00 \mathrm{ml}$ titanium(IV) isopropoxide (TTIP) in $16.66 \mathrm{ml}$

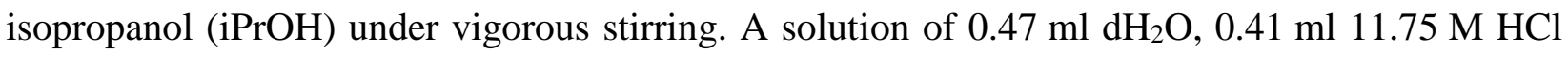
and $16.66 \mathrm{ml} \mathrm{iPrOH}$ was added dropwise to hydrolyse the precursor sol under acidic conditions at $4^{\circ} \mathrm{C}$. The molar ratios of the derived $\mathrm{TiO}_{2}$ sol were TTIP: $\mathrm{dH}_{2} \mathrm{O}: \mathrm{iPrOH}: \mathrm{HCl}=1: 2: 21.5: 0.24$. The derived sol was aged for $24 \mathrm{~h}$ at $4^{\circ} \mathrm{C}$ before being used in the coating process. All chemicals were purchased from Sigma Aldrich (St. Louis, Missouri, USA).

Prior to dip-coating, the substrates $\left(\mathrm{TiO}_{2}\right.$ scaffolds, $\mathrm{TiO}_{2}$ discs and $\mathrm{Si}$ wafers) were bath sonicated in trichloroethylene, ethanol and $\mathrm{dH}_{2} \mathrm{O}$ for $10 \mathrm{~min}$ and dried at $37^{\circ} \mathrm{C}$ for $24 \mathrm{~h}$. The cleaned samples were then dipped into the $\mathrm{TiO}_{2}$ sol and withdrawn at a constant speed of $10 \mathrm{~cm} \mathrm{~min}^{-1}$ using a custom-made dip-coating machine. Samples were dried at $120^{\circ} \mathrm{C}$ for $1 \mathrm{~h}$ before the deposited film was calcined at $500^{\circ} \mathrm{C}$ for $1 \mathrm{~h}$. Heating and cooling rates were set to $1 \mathrm{~K} \mathrm{~min}^{-1}$ (HTC-08/16, Nabertherm GmbH, Bremen, Germany).

' $\mathrm{H}_{2} \mathrm{O}_{2}$-treated' samples were immersed in $30 \% \mathrm{H}_{2} \mathrm{O}_{2}$ for $1 \mathrm{~h}$ at $\mathrm{RT}$ and subsequently dried at $37^{\circ} \mathrm{C}$ for $24 \mathrm{~h}$. Discs used in the in vitro assays of this study were steam sterilised at $120^{\circ} \mathrm{C}$ for $20 \mathrm{~min}$ before the $\mathrm{H}_{2} \mathrm{O}_{2}$ pre-treatment and afterwards handled aseptically. 


\subsection{Surface characterisation}

\subsubsection{Coating quality}

Coated scaffolds and discs were qualitatively compared to uncoated substrates by scanning electron microscopy (SEM). Samples were sputter coated with platinum and two randomly chosen areas on each sample were imaged with a SE microscope (TM-3030, Hitachi, Tokyo, Japan) at an accelerating voltage of $15 \mathrm{kV}$. The visual examination focused on homogeneity of the coating, changes in grain boundary appearances and blocked pore windows for $\mathrm{TiO}_{2}$ scaffolds. Additional higher resolution imaging was performed using a field emission SEM (S-4800, Hitachi, Tokyo, Japan).

\subsubsection{Surface topography and coating thickness}

The topography of coated and uncoated coins was visualised and quantified by profilometry (PLspecs, Sensofar, Terrassa, Spain). An area of $0.29 \times 0.29 \mathrm{~mm}^{2}$ was scanned at a random position on each sample at a magnification of $150 \times$ in true colour mode at $12 \%$ light intensity. The scanning depth was $14 \mu \mathrm{m}$ and images were analysed using the integrated SensoMap software to determine the surface roughness $\left(\mathrm{S}_{\mathrm{a}}\right)$. In addition, coated $\mathrm{Si}$ wafers and polished $\mathrm{TiO}_{2}$ coins (Exakt $400 \mathrm{CS}$ microgrinder, Norderstedt, Germany; sequential polishing with abrasive SiC grinding papers of gradually increasing grits from P600 to P4000) were used to assess the nanotopography of the coating surface using atomic force microscope (MFP-3D-SA, Asylum Research, Santa Barbara, CA, USA) in combination with OMCL-AC240TS cantilevers (Olympus, Shinjuku-ku, Japan). An area of $20 \times 20 \mu \mathrm{m}^{2}$ was scanned at a random position on each sample and surface roughness $\left(S_{a, p o l i s h e d}\right)$ was determined using the open source software Gwyddion $(n=3)$.

The coating thickness was measured on Si (100) substrates by spectroscopic ellipsometry (alfa-SE, J.A., Woolam, NE) in the wavelength range of $390-900 \mathrm{~nm}$. The integrated software CompleteEASE was used to quantify the thickness by fitting the data to a Cauchy function.

\subsubsection{Crystal structure}

The crystal phase of the calcined films was determined by X-ray diffraction (XRD) in grazing incident configuration. Crystallinity was measured on Si wafers which were coated and calcined three consecutive times. Measurements were performed with a Ge (111) monochrometer providing $\mathrm{CuK} \alpha_{1}$ irradiation, LynxEye detector (Bruker, Karlsruhe, Germany) in Bragg-Brenato geometry $\theta$ $-2 \theta$. 


\subsubsection{Water contact angle}

Water contact angles (WCA) of coated and uncoated polished $\mathrm{TiO}_{2}$ coins were determined before and after $\mathrm{H}_{2} \mathrm{O}_{2}$ exposure $\left(\mathrm{H}_{2} \mathrm{O}_{2}\right.$-treated surface) using an optical contact angle measuring system (OCA 20, DataPhysics Instruments, Filderstadt, Germany. Contour of a $2 \mu 1$ sessile drop of deionised water on $\mathrm{TiO}_{2}$ sample surfaces was recorded at room temperature and contact angle was determined using the ellipse fitting for $30^{\circ}<\mathrm{WCA}<90^{\circ}$ and tangent fitting for WCA $<30^{\circ}(n=$ $5)$.

\subsubsection{Catalytic activity}

The oxidative power of modified $\mathrm{TiO}_{2}$ scaffolds was quantified by the degradation of $\mathrm{MB}$. Coated and uncoated samples were investigated in two different experimental setups. In the first setup, the degradation of $\mathrm{MB}$ was determined in the presence of $3 \% \mathrm{H}_{2} \mathrm{O}_{2}$. For the second setup, scaffolds were pre-treated with $\mathrm{H}_{2} \mathrm{O}_{2}$ as described above and $\mathrm{H}_{2} \mathrm{O}_{2}$ was not present during the degradation. $\mathrm{TiO}_{2}$ scaffolds coated with an anatase thin film using atomic layer deposition (ALD) at $250^{\circ} \mathrm{C}$ as described in detail by Müller et al. ${ }^{34}$ were used as additional control in the first setup in order to determine the effect of crystal structure on MB degradation.

Six scaffolds per group were placed in six-well plates (Nunc ${ }^{\mathrm{TM}}$, Roskilde, Denmark). All wells were filled with $10 \mathrm{ml} 0.03 \mathrm{mM} \mathrm{MB}$ either with or without $3 \% \mathrm{H}_{2} \mathrm{O}_{2}$ depending on which setup was used. Well plates were placed on an orbital shaker at moderate shaking and immediately covered with an aluminium cover to avoid irradiation with ambient light. The cover was shortly removed to take samples of $1.5 \mathrm{ml}$ at $0,15,30,45,60,90,120,150$ and $180 \mathrm{~min}$. Samples were transferred to disposable cuvettes and the absorbance was measured spectrophotometrically (Lambda 25, Perkin Elmer instruments, MA, USA) for a wavelength range of 500-750 nm. No peak shifts over time were detected in a preliminary study and the degradation of MB is given for the peak absorbance at $664 \mathrm{~nm}$. Samples were returned to each well after analysis. All groups were tested in triplicates $(n=3)$.

\subsection{Biological response: bacteria}

\subsubsection{Bacteria culture}

The genetically modified strain S. epidermidis Xen43 was used as a model for the colonisation of $\mathrm{TiO}_{2}$ surfaces. The insertion of the luxABCDE gene cassette into the clinical isolate $S$. epidermidis 1457 resulted in the constitutive luminescent derivative strain Xen43. ${ }^{35}$ S. epidermidis Xen43 has 
been shown to be phenotypically equal to its parental strain ${ }^{35}$ and was kept as frozen stock cultures at $-80^{\circ} \mathrm{C}$ to prevent phenotypic changes due to passaging. The frozen stock cultures were thawed and grown in tryptic soy broth (TSB) at $37^{\circ} \mathrm{C}$ to an optical density at $600 \mathrm{~nm}\left(\mathrm{OD}_{600}\right)$ of 0.05 . Cultures were then incubated for $24 \mathrm{~h}$ and diluted 1:100 in TSB for overnight cultures. This step was repeated to achieve double overnight (DO) cultures which were adjusted to $\mathrm{OD}_{600}=0.05$ $\left(\sim 1 \times 10^{7} \text { cells } \mathrm{ml}^{-1}\right)^{36}$ and immediately used to contaminate $\mathrm{TiO}_{2}$ discs.

A modified direct contact test was used to assess the antibacterial activity of the surface modification. Three coins per group were placed in a 24-well plate (Nunc ${ }^{\mathrm{TM}}$, Roskilde, Denmark) and contaminated by placing a $20 \mu 1$ droplet of DO cultures $\left(\sim 2 \times 10^{5}\right.$ cells $)$ in the centre of the coin. After an initial attachment phase of $15 \mathrm{~min}$ at RT wells were carefully filled with $500 \mu \mathrm{l}$ prewarmed TSB before further analysis.

\subsubsection{Metabolic activity}

The colonisation of $\mathrm{TiO}_{2}$ surfaces by $S$. epidermidis was measured by monitoring luminescence during incubation for $12 \mathrm{~h}$. Therefore, plates were sealed (TopSeal ${ }^{\mathrm{TM}}$ A-Plus, Perkin Elmer, Waltham, MA, USA) and incubated at $37^{\circ} \mathrm{C}$ in a multi-detection microplate reader (Synergy HT, BioTek, Winooski, USA). Luminescence was measured as relative light units (RLU) every 15 min after $10 \mathrm{~s}$ of moderate, orbital shaking. The maximum RLU peak intensities are referred to as $\mathrm{RLU}_{\max }$ in this study. Luminescence experiments were run in triplicates for test groups $(n=9)$ and control surfaces which were not inoculated with bacteria $(n=3)$.

\subsubsection{Viability}

The viability of the biofilm was assessed by the number of colony forming units (CFU) on the $\mathrm{TiO}_{2}$ surface $4 \mathrm{~h}$ and $12 \mathrm{~h}$ after contamination. At each time point, one disc per group was carefully placed in a new 24-well plate and washed with sterile phosphate buffered saline (PBS) twice to remove non-adherent bacteria. Wells were filled $1 \mathrm{ml} \mathrm{PBS}$ and bath sonicated $(37 \mathrm{kHz}, 20 \mathrm{~W})$ at $37^{\circ} \mathrm{C}$ for 3 min to detach adherent bacteria. After sonication the bacterial suspensions was collected, diluted in PBS and $3 \times 20 \mu$ d droplets were plated on TSB agar plates. CFUs were counted manually $12 \mathrm{~h}$ after incubation at $37^{\circ} \mathrm{C}$. Control discs which were not inoculated with bacteria were plated accordingly to verify the absence of microbes for aseptically handled discs. CFU experiments were performed in three independent $(n=9)$ runs and data is presented as the mean of means. 


\subsubsection{Bacteria morphology}

Scanning electron microscopy (SEM) and fluorescence microscopy after live/dead staining were performed $4 \mathrm{~h}$ and $12 \mathrm{~h}$ after contamination. Samples for SEM were transferred into a new 24-well plate and fixated with $2.5 \%$ glutaraldehyde in $0.1 \mathrm{M}$ Sørensen's phosphate buffer for $24 \mathrm{~h}$. Subsequently, samples were washed with PBS twice, dried in ethanol (70 - 100\%), sputter coated with platinum and imaged (S-4800, Hitachi, Tokyo, Japan) at an accelerating voltage of $5 \mathrm{kV}$. Samples for fluorescence microscopy were prepared using a Live/Dead BacLight bacterial viability kit (Molecular Probes Inc., Eugene, USA). $\mathrm{TiO}_{2}$ discs were placed in a new 24-well plate and stained with a 1:1 mixture of propidium iodide and SYTO9 (both in ultrapure milliQ water) at RT for $15 \mathrm{~min}$ in darkness. Afterwards, samples were carefully washed with PBS twice to remove excessive dye and non-adherent bacteria. A coverslip was fixated onto the $\mathrm{TiO}_{2}$ surface before imaging. Images were taken as full projection of $30 \mu \mathrm{m} \mathrm{z}$-stacks at a magnification of $40 \times$ with a confocal fluorescence microscope (DM 6000 CFS, Leica, Wetzland, Germany). SEM and fluorescence images were taken at two randomly chosen spots of each coin $(n=6)$.

\subsection{Biological response: osteoblastic cells}

\subsubsection{Cell culture}

The osteoblastic mouse cell line MC3T3-E1 (DSMZ, Braunschweig, Germany) was used as a model for the biological response of cells towards modified and unmodified $\mathrm{TiO}_{2}$ surfaces. Cells were cultured in alpha-MEM supplemented with $10 \%$ fetal bovine serum and an antibiotic mix of $50 \mathrm{U} \mathrm{ml}^{-1}$ penicillin and $50 \mu \mathrm{g} \mathrm{ml}^{-1}$ streptomycin at $37^{\circ} \mathrm{C}$ in a humidified atmosphere of $5 \% \mathrm{CO}_{2}$. All experiments were carried out after 20 passages.

Six $\mathrm{TiO}_{2}$ discs per group were placed in a 24-well plate and a $20 \mu$ l droplet of cell suspension $\left(2 \times 10^{4}\right.$ cells $)$ was carefully placed in the centre of each disc. Cells cultured on tissue culture plastic (TCP) functioned as a control group. After an initial attachment phase of $15 \mathrm{~min}$ in RT, wells were carefully filled with culture media and incubated for $24 \mathrm{~h}$. Colonised discs were used for genotoxicity $(n=3)$ and cell morphological analysis $(n=3)$. Culture media was collected for cytotoxicity analysis $(n=6)$. 


\subsubsection{Genotoxicity}

An alkaline comet assay was used to quantify permanent DNA damage in MC3T3-E1 cells attached to $\mathrm{TiO}_{2}$ surfaces. Cells were detached from discs after $24 \mathrm{~h}$ by trypsin/EDTA, re-suspended in $1.2 \mathrm{ml}$ culture media and immediately put on ice. After centrifugation $(5 \mathrm{~min}$ at $0.2 \mathrm{G})$ the supernatant was removed and the cell pellet was mixed in $44 \mu$ l low melting point agarose. The agarose-cell suspension was divided into two equal drops of $20 \mu \mathrm{l}$ and placed on an agarose coated microscope slide. Slides were stored at $4^{\circ} \mathrm{C}$ for $10 \mathrm{~min}$ for complete gelation. A high control (cells on TCP) was placed in a slide holder filled with cold $3 \% \mathrm{H}_{2} \mathrm{O}_{2}$ for $5 \mathrm{~min}$. All slides were then placed in slide holders filled with a cold lysis solution $(2.5 \mathrm{M} \mathrm{NaCl}, 0.1 \mathrm{M}$ EDTA, $10 \mathrm{mM}$ Tris$\mathrm{HCl}, \mathrm{pH} 10,1 \%$ triton $\mathrm{X}-100)$ and stored at $4{ }^{\circ} \mathrm{C}$ for $1 \mathrm{~h}$. All slides were placed in alkaline electrophoresis solution ( $0.3 \mathrm{M} \mathrm{NaOH}, 1 \mathrm{mM}$ EDTA) for $20 \mathrm{~min}$ at $4{ }^{\circ} \mathrm{C}$ for DNA unwinding before electrophoresis was run for $30 \mathrm{~min}$ at $25 \mathrm{~V}$ and $350 \mathrm{~mA}$. Slides were neutralised with cold PBS and $\mathrm{dH}_{2} \mathrm{O}$ for 10 min each and dried overnight at RT.

Nuclei were stained with SYBR gold (Thermo Scientific, Waltham, MA, USA) at RT for 15 min in darkness shortly before imaging. Slides were analysed using a fluorescence microscope (DM6000 FS, Leica, Wetzland, Germany). At least 50 nuclei per droplet (100 per sample) were imaged and analysed using the OpenComet plugin for ImageJ. Results of the comet assay are given as \%DNA in tail.

\subsubsection{Cytotoxicity}

Lactate dehydrogenase (LDH) activity was measured as an indicator for membrane related cell death. $100 \mu \mathrm{l}$ of cell culture medium was collected after $24 \mathrm{~h}$ and mixed 1:1 with a reaction mixture according to manufacturer instructions (Cytotoxicity detection kit, Roche Diagnostics, Mannheim, Germany), and incubated at RT for $30 \mathrm{~min}$. The oxidation of $\mathrm{NADH}$ was measured spectrophotometrically (ELx800, BioTek Instruments, VT, USA) at $490 \mathrm{~nm}$. Results for $\mathrm{TiO}_{2}$ test groups are given relative to a low control (cells on TCP) and a high control (cells on TCP with 1\% triton $\mathrm{X}-100)$ according to the following equation:

Cytotoxicity $(\%)=($ sample - low control $) /($ high control - low control $) \times 100$

\subsubsection{Cell morphology}

MC3T3-E1 cells attached on $\mathrm{TiO}_{2}$ discs were stained with DAPI and Alexa Phalloidin 488 for fluorescent imaging to assess differences in cell morphology. Cells were carefully washed with 
sterile, calcium and magnesium free PBS and fixated with 4\% paraformaldehyde for 20 min at RT. Afterwards, paraformaldehyde was removed and samples were washed with PBS before stained with $5 \mu \mathrm{g} \mathrm{ml}^{-1}$ Alexa Phalloidin 488 (in PBS) for $30 \mathrm{~min}$ at RT in darkness. Samples were subsequently washed with PBS and stained with 300 nM DAPI (in PBS + 1\% triton X-100) for 15 min at RT in darkness. A cover slip was fixed onto the surface and samples were analysed using a confocal fluorescence microscope (DM 6000 CFS, Leica, Wetzland, Germany). Images were taken at two randomly chosen spots of the coin surface as full projections of a $150 \mu \mathrm{m}$ z-stack. Differences in cell morphology between the groups were assessed qualitatively in this study.

\subsection{Statistical analysis}

Normality (Shapiro-Wilk) and equal variance (Brown-Forsythe) was tested prior to further statistical analysis. Datasets were compared using Student's $t$-test or one-way analysis of variance (ANOVA) test and subsequent post hoc analysis for pairwise comparison by the Holm-Sidak method. Statistical significant differences were considered for $p<0.05$ and highlighted with an asterisk. All statistical analyses were performed using SigmaPlot 13.0 (Systat Software Inc., Chicago, IL, USA).

\section{Results and discussion}

\subsection{Coating characteristics}

The dark catalytic effect of $\mathrm{TiO}_{2}$ describes the decomposition of $\mathrm{H}_{2} \mathrm{O}_{2}$ on $\mathrm{TiO}_{2}$ via radical intermediates in the absence of light. The radicals formed are highly oxidative and essential for the high antibacterial activity found in $\mathrm{TiO}_{2}-\mathrm{H}_{2} \mathrm{O}_{2}$ suspensions. ${ }^{36}$ Since anatase has been suggested to be the more active phase in the catalytic decomposition of $\mathrm{H}_{2} \mathrm{O}_{2}$ on $\mathrm{TiO}_{2}$ compared to rutile, ${ }^{26}$ the aim of the applied surface modification was to deposit a thin anatase layer onto the underlying rutile surface of the prepared porous $\mathrm{TiO}_{2}$ substrates. The rutile phase of the used $\mathrm{TiO}_{2} \mathrm{scaffolds}$ used in this study is an inevitable consequence of the high sintering temperatures required to achieve adequate mechanical strength needed in load bearing applications. ${ }^{21}$

The dip-coating of $\mathrm{TiO}_{2}$ scaffolds in a TTIP-based sol and subsequent heat treatment resulted in a thin film with a thickness of $42 \pm 12 \mathrm{~nm}$ that homogeneously covered the entire surface of the substrate (Figure 1, Figure 2). Most importantly, the interconnective pore architecture, a key 
structural parameter for bone tissue engineering, ${ }^{32}$ remained intact after the coating process (Figure 1). Defect free dip-coating of porous substrates is generally challenging and the outcome is strongly depending on the film thickness. ${ }^{37}$ A too thick coating may close pore windows or form flakes, while complete coverage of the substrate is often not achieved for too thin coatings. The applied coating layer was thin enough to uniformly coat the underlying grains of the substrate and even infiltrate the grain boundaries, which explains the significantly lower roughness measured on the coated $\left(\mathrm{S}_{\mathrm{a}}=0.54 \pm 0.05 \mu \mathrm{m}\right)$ than the uncoated $\left(\mathrm{S}_{\mathrm{a}}=1.15 \pm 0.22 \mu \mathrm{m}\right) \mathrm{TiO}_{2}$ surfaces. Further, similar nanoscale surface roughness values with no statistically significant difference were measured for both coated $\left(S_{a \text {,polished }}=25.6 \pm 23.2 \mathrm{~nm}\right)$ and uncoated $\left(S_{\text {a,polished }}=40.9 \pm 22.9 \mathrm{~nm}\right)$ on polished $\mathrm{TiO}_{2}$ coins, and no distinct nanostructures were observed on sol-gel coated Si wafers as shown in Figure 2. However, grain boundaries were found to be the areas that were most susceptible to coating defects. Thin cracks were observed along the initial grain boundaries (Figure1, Figure 2) which may appear upon internal stresses during calcination, ${ }^{37}$ and could possibly be avoided by lower heating rates.

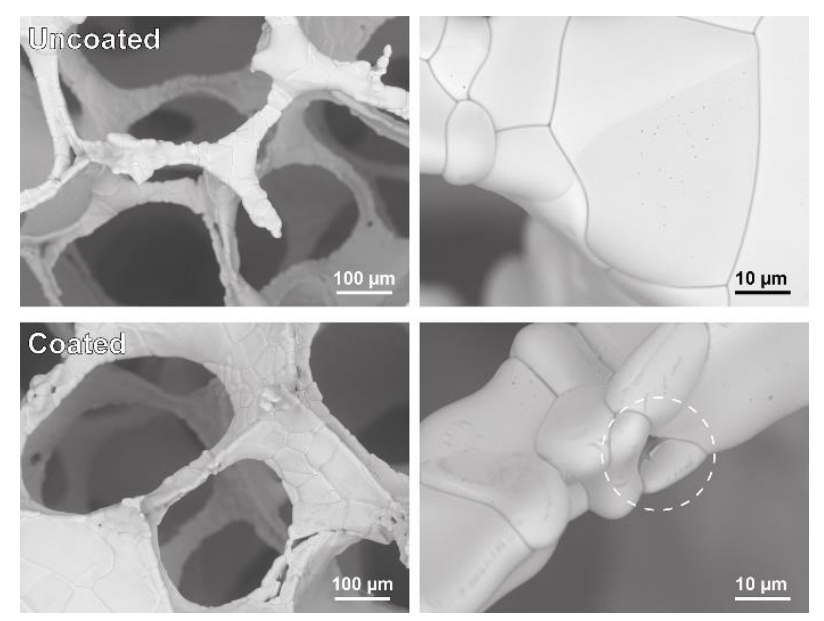

Figure 1. SEM images showing the porous microstructure of uncoated and sol-gel coated $\mathrm{TiO}_{2}$ scaffolds. Dashed circle highlights a minor delamination defect on a coated strut. 

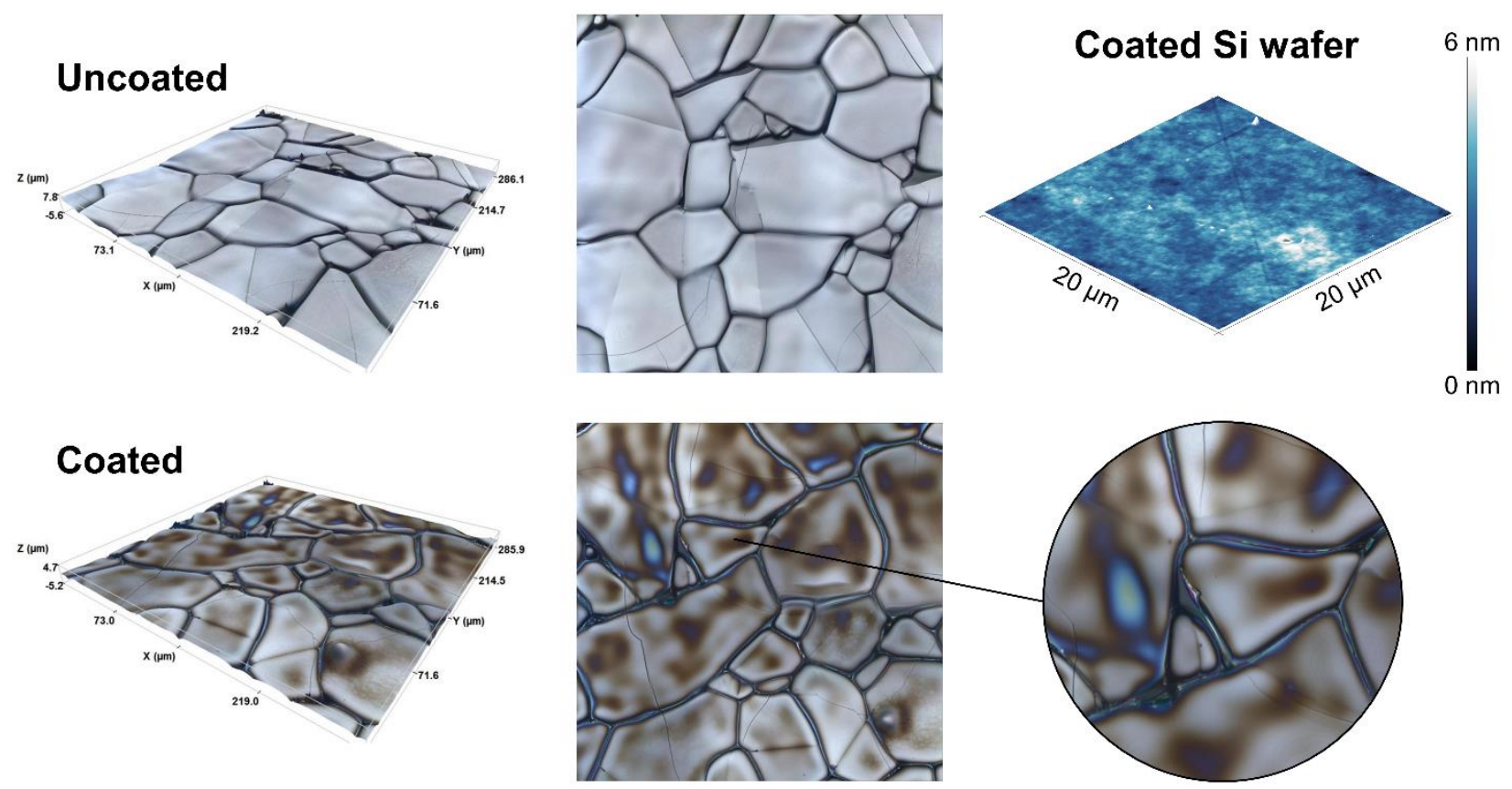

Figure 2. Surface topography of uncoated and coated $\mathrm{TiO}_{2}$ discs. Thin cracks along original grain boundaries of the $\mathrm{TiO}_{2}$ substrate were observed on the coated surfaces as seen in the highlighted area. Nanoscale topography of the coating surface is illustrated on a sol-gel coated Si wafer.

While not altering the surface topography of the $\mathrm{TiO}_{2}$ substrate, the sol-gel coating was observed to have a significant impact on the wettability of the $\mathrm{TiO}_{2}$ coin surfaces as the coated surfaces were significantly more hydrophilic in comparison to the uncoated coin surfaces $\left(\mathrm{WCA}_{\text {coated }}=9.7 \pm 4.2^{\circ}\right.$ $v s$. $\left.\mathrm{WCA}_{\text {uncoated }}=79.2 \pm 7.6^{\circ}, p<0.001\right)$. This significant increase in wettability of the sol-gel coated surfaces maybe caused by the thin cracks observed along the grain boundaries of the underlying substrate as these defects may wick the applied water droplet onto the surface of the coin. However, a significant decrease in the wetting behaviour of the coated $\mathrm{TiO}_{2}$ surfaces was observed following exposure to $30 \% \mathrm{H}_{2} \mathrm{O}_{2}$ (WCA ${\text { coated, } \mathrm{H}_{2} \mathrm{O}_{2}}=42.4 \pm 5.4^{\circ}, p<0.001$ ), which indicates that the capillary action of physical defects in the coating are not the reason for the very hydrophilic surface of the sol-gel coating. Significant increase in WCA was also observed for the uncoated $\mathrm{H}_{2} \mathrm{O}_{2}$-treated samples ( $\left(\mathrm{WCA}_{\text {uncoated, } \mathrm{H}_{2} \mathrm{O}_{2}}=91.2 \pm 7.4^{\circ}, p<0.01\right.$ ). Therefore, the presence of more abundant surface hydroxyl groups on the sol-gel coated surfaces as a consequence of higher number of oxygen vacancies present in the anatase coating than in the rutile substrate may likely be responsible for the hydrophilicity of the coated $\mathrm{TiO}_{2}$ surfaces. ${ }^{38-39}$ 
$\mathrm{XRD}$ analysis revealed that anatase was the predominant crystal phase of the applied $\mathrm{TiO}_{2}$ coating (Figure 3). The phase transformation from anatase to rutile has been reported to begin at approximately $600^{\circ} \mathrm{C}$ in similar sol-gel systems, ${ }^{40-41}$ which explains the absence of rutile peaks in the diffraction pattern. Surprisingly, no crystalline structures could be observed with either SEM or AFM (Figure 1, Figure 2), and repeated coating cycles were necessary to achieve adequate signal intensity in XRD analysis. This may be explained by the low thickness of the deposited film $(42 \pm 12 \mathrm{~nm})$. Yu et al., for example, could not detect crystalline peaks in XRD patterns for coatings when the film thickness was below $0.46 \mu \mathrm{m}$ but confirmed crystallinity of the films by transmission electron microscopy (TEM). ${ }^{42}$

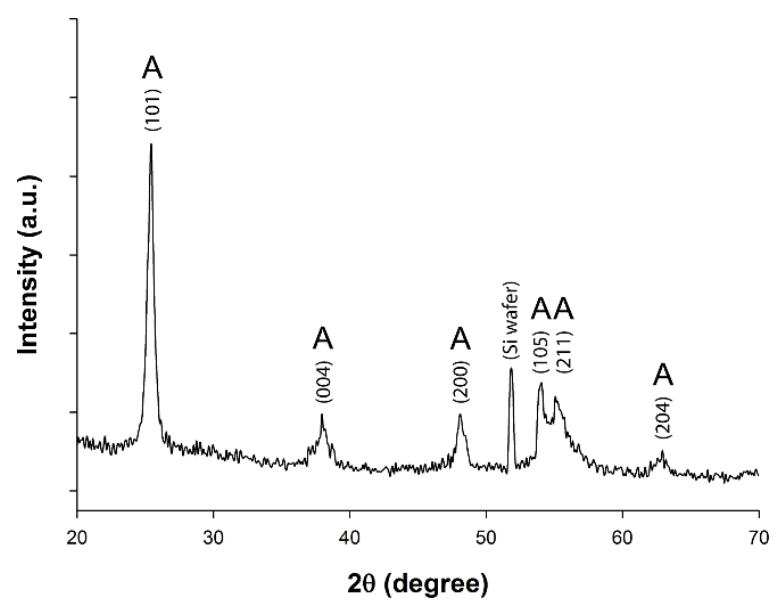

Figure 3. X-ray diffraction pattern of sol-gel coated Si (100) wafer following calcination at $500^{\circ} \mathrm{C}$ for $1 \mathrm{~h}$ revealed characteristic peaks for anatase crystal structure (A) together with a reflection from the underlying Si substrate.

The sol-gel coated $\mathrm{TiO}_{2}$ scaffolds showed a significantly stronger catalytic activity compared to the uncoated samples both in the presence of $3 \% \mathrm{H}_{2} \mathrm{O}_{2}$ and following the pre-treatment of the scaffold surface with $30 \% \mathrm{H}_{2} \mathrm{O}_{2}$ (Figure 4). The degradation of $\mathrm{MB}$ by the coated surfaces was continuous over $3 \mathrm{~h}$ and was accompanied by the formation bubbles in the presence of $3 \% \mathrm{H}_{2} \mathrm{O}_{2}$. Further, similar bubble formation was also observed during the $\mathrm{H}_{2} \mathrm{O}_{2}$ pre-treatment, with the bubbling effect being considerably more pronounced for the sol-gel coated scaffolds. 

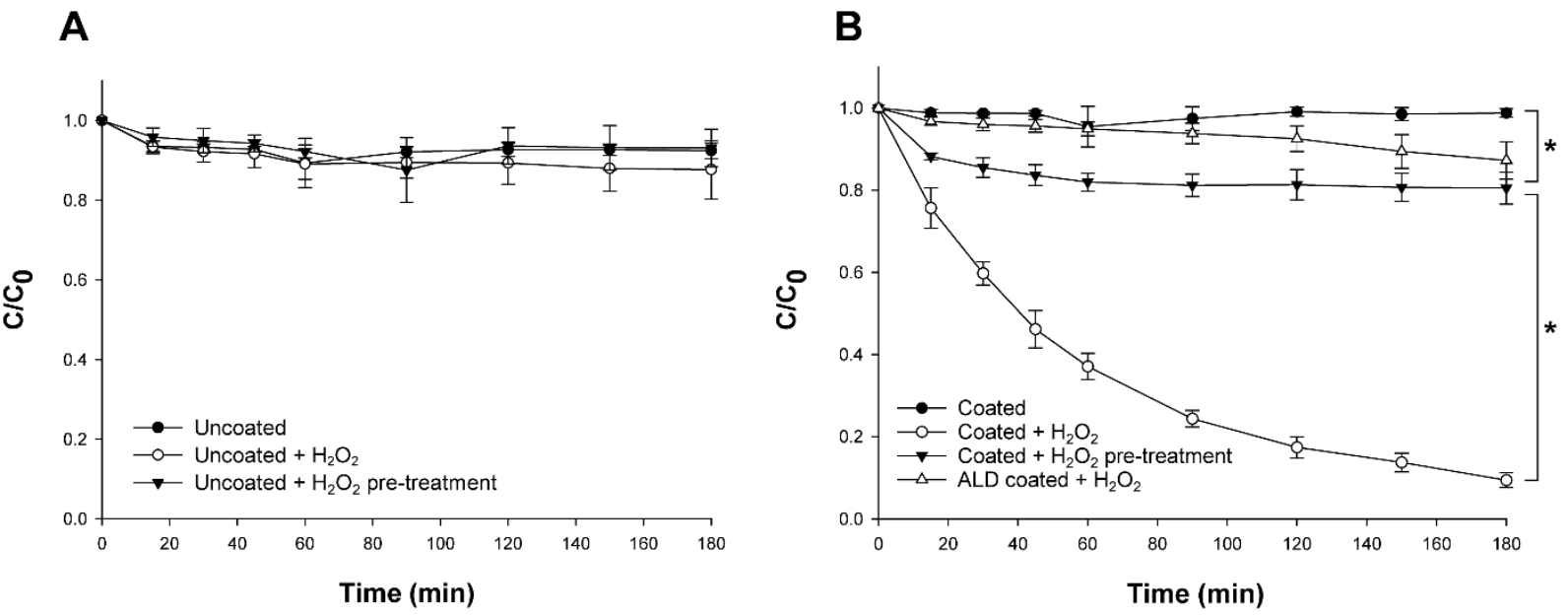

Figure 4. Normalised degradation of methylene blue by $(\mathbf{A})$ uncoated and $(\mathbf{B})$ anatase-coated $\mathrm{TiO}_{2}$ scaffolds (mean $\pm \mathrm{SD}, n=3, * p<0.05$ ). The coated scaffolds showed significantly higher MB degradation than the uncoated scaffolds both in the presence of $3 \% \mathrm{H}_{2} \mathrm{O}_{2}$ and after pre-treatment with $30 \% \mathrm{H}_{2} \mathrm{O}_{2}$. ALD coated samples showed similar $\mathrm{MB}$ degradation as the uncoated samples in the presence of $3 \% \mathrm{H}_{2} \mathrm{O}_{2}$. No change in $\mathrm{MB}$ concentration was observed in the absence of $\mathrm{TiO}_{2}$ scaffolds.

Taken together, these results indicate that $\mathrm{H}_{2} \mathrm{O}_{2}$ is decomposed into water and oxygen at the liquid$\mathrm{TiO}_{2}$ interface via radical intermediates, which are responsible for the decomposition of the organic dye. Several authors have proposed the following pathway for the decomposition of $\mathrm{H}_{2} \mathrm{O}_{2}$ on metal oxides: ${ }^{43-44}$

$$
\begin{array}{lll}
\mathrm{H}_{2} \mathrm{O}_{2}+\mathrm{M} & \rightarrow & 2 \cdot \mathrm{OH}+\mathrm{M} \\
\bullet \mathrm{OH}+\mathrm{H}_{2} \mathrm{O}_{2} & \rightarrow & \mathrm{HO}_{2}^{\bullet}+\mathrm{H}_{2} \mathrm{O} \\
2 \mathrm{HO}_{2} & \rightarrow & \mathrm{H}_{2} \mathrm{O}_{2}+\mathrm{O}_{2}
\end{array}
$$

where $M$ is an unspecific active site at the liquid-metal oxide interface. This reaction has been shown for several metal oxides with different rate constants for the $\mathrm{H}_{2} \mathrm{O}_{2}$ decomposition. ${ }^{45}$ The superior degradation of $\mathrm{MB}$ on the sol-gel coated $\mathrm{TiO}_{2}$ scaffolds suggests that active sites are either more efficient or abundant on anatase surfaces, and thereby, indicaties that the crystal structure of the metal oxide may influence $\mathrm{H}_{2} \mathrm{O}_{2}$ decomposition reaction on $\mathrm{TiO}_{2}$ surfaces. This observation is in line with previous $\mathrm{MB}$ degradation results by $\mathrm{TiO}_{2}$ particles dispersed in $3 \% \mathrm{H}_{2} \mathrm{O}_{2}$ solution. ${ }^{26}$ However, it is not solely the crystal phase the influences the catalytic activity of the $\mathrm{TiO}_{2}$ surface 
as scaffolds coated by atomic layer deposited anatase thin film showed similarly low catalytic activity for MB degradation as the uncoated rutile substrate (Figure 4B), despite their increased surface area due to the distinct nanostructure of the deposited anatase film. ${ }^{34}$ As these surfaces also featured similar wettability as the uncoated $\mathrm{TiO}_{2},{ }^{34}$ the presence of more abundant oxygen vacancies on the surface of the sol-gel coated scaffolds is a likely explanation for their significantly stronger oxidative power in the presence of $\mathrm{H}_{2} \mathrm{O}_{2}$. Whereas the sequential film growth reaction in ALD process is highly controlled, ${ }^{46}$ the hydrolysis and polymerisation steps in the sol-gel coating process are far less controllable, ${ }^{47}$ which in combination with the relatively short sintering time in low oxygen environment is likely to contribute to formation of surface point defects. Point defects play an important role in heterogeneous catalysis, while reduced coordination of the metal ions has been shown to accurately describe the catalytic decomposition of $\mathrm{H}_{2} \mathrm{O}_{2}$ on transition metal oxides in theoretical models. ${ }^{44}$ Therefore, a more thorough-chemical characterisation of the coated $\mathrm{TiO}_{2}$ surfaces is needed to clarify the role of the crystal phase and presence of lattice defects in the decomposition of $\mathrm{H}_{2} \mathrm{O}_{2}$ on $\mathrm{TiO}_{2}$.

Nonetheless, the results of the degradation study indicate that the oxidative behaviour of $\mathrm{TiO}_{2}$ $\mathrm{H}_{2} \mathrm{O}_{2}$ suspensions in the absence of light can also be observed for $\mathrm{TiO}_{2}$ surfaces. The reaction with intermediate free radicals (reaction $1 \& 2$ ) are the most likely cause for complete decomposition of the model dye. Hydroxyl radical $\left({ }^{\bullet} \mathrm{OH}\right)$ is a powerful oxidant and capable of decomposing various compounds in water. However, a previous study has pointed out the importance of superoxide $\left(\mathrm{O}_{2}{ }^{-}\right.$ •) and hydroperoxyl radicals $\left(\mathrm{HO}_{2}{ }^{\circ}\right)$ in the destruction of organic dyes. ${ }^{26} \mathrm{HO}_{2}{ }^{\bullet}$ is the protonated form of the $\mathrm{O}_{2}^{-\bullet}$ which has been shown to adsorb on the surface of several metal oxides. ${ }^{30} \mathrm{O}_{2}{ }^{-\bullet}$ coordinated at a $\mathrm{Ti}^{\mathrm{IV}}$ site have been shown to be stable in air for several days ${ }^{48}$ and may therefore explain the oxidative effect of coated scaffolds also after the pre-treatment with $\mathrm{H}_{2} \mathrm{O}_{2}$ (Figure 4B).

The biomedical implications of stabilised superoxide radicals have been studied to some extent. In their pioneering work, Tengvall et al. investigated the role of superoxide radicals bound in a TiOOH matrix formed during the interaction of metallic titanium and $\mathrm{H}_{2} \mathrm{O}_{2}{ }^{31,49}$ The interaction of host tissue cells with the $\mathrm{TiOOH}$ matrix has been suggested to be essential for the biocompatibility of titanium in vivo. ${ }^{50}$ Further, several groups have utilised the stabilisation of free radicals for a prolonged antibacterial effect of implant surfaces, ${ }^{25,} 51$ and therefore, the biological response towards oxidative $\mathrm{TiO}_{2}$ scaffolds used in this study was assessed in two in vitro assays. 


\subsection{Antibacterial activity}

Staphylococci implant colonisation has been reported to be the most frequent cause for biomaterialassociated infections related to orthopaedic devices. ${ }^{7,}{ }^{52}$ Both S. epidermidis and S. aureus are commensal bacteria which become pathogenic by passing the skin barrier and entering the implantation site during surgery. ${ }^{52}$ While $S$. aureus is considered the more virulent strain, the outstanding role of $S$. epidermidis in BAI is due to its ability to from a pathogenic biofilm on implant surfaces. ${ }^{53-54}$ Bacterial biofilms show low susceptibility against antibiotic therapy and can evade the host immune system, which make staphylococcal infections particularly difficult to treat. The ability to form such biofilms on various substrates in a monoculture in vitro has made $S$. epidermidis a valuable and well-established model strain in the assessment of antibacterial surfaces. It was therefore selected as a biofilm model in the presented study. The use of the constitutive luminescent strain Xen43 further allowed us to monitor luminescence as an indicator for the metabolic activity ${ }^{35}$ and viability ${ }^{36}$ during the colonisation of the modified $\mathrm{TiO}_{2}$ surfaces.
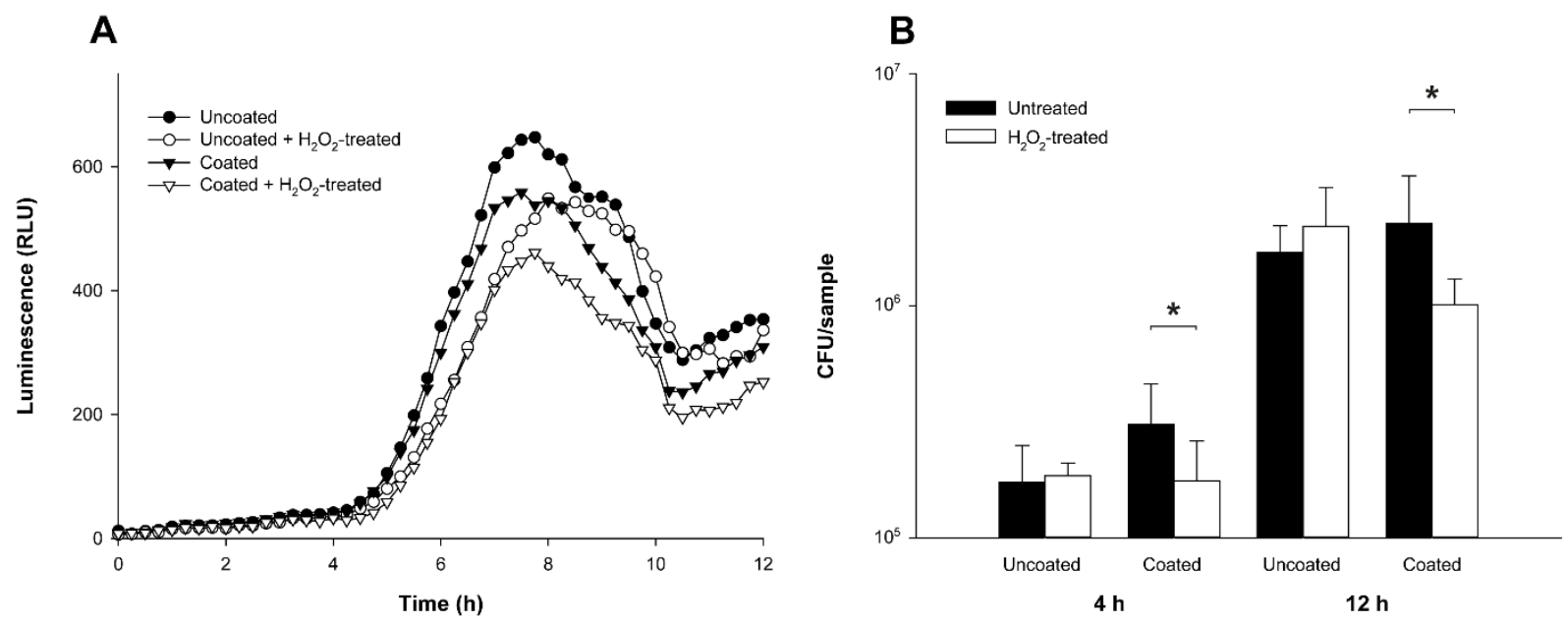

Figure 5. (A) Characteristic luminescence curves for $\mathrm{TiO}_{2}$ surfaces contaminated with $S$. epidermidis Xen43 (mean values presented for each timepoint, $n=9$ ) and $(\mathbf{B})$ the colony-forming units detached from the $\mathrm{TiO}_{2}$ surfaces after $4 \mathrm{~h}$ and $12 \mathrm{~h}$ incubation (mean of means $\pm \mathrm{SD}, n=3 \times 3$, $* p<0.05)$. Statistically significant reduction of viable adherent bacteria was observed on the anatase-coated $\mathrm{TiO}_{2}$ surfaces pre-treated with $30 \% \mathrm{H}_{2} \mathrm{O}_{2}$. 
The results of the in vitro assays demonstrate that $\mathrm{TiO}_{2}$ sol-gel coatings show antibacterial activity against $S$. epidermidis after the treatment with $\mathrm{H}_{2} \mathrm{O}_{2}$. A delay in $\mathrm{RLU}_{\max }$ and a lower overall peak intensity was observed for the $\mathrm{H}_{2} \mathrm{O}_{2}$-treated sol-gel coated $\mathrm{TiO}_{2}$ surfaces compared to samples not exposed to $\mathrm{H}_{2} \mathrm{O}_{2}$ (Figure 5A). These observations are likely to result from the lower total number of viable bacteria on the sample surface following the initial bacterial attachment period and early observation timepoints (Figure 6), which was further confirmed by the significantly reduced number of CFUs observed for the $\mathrm{H}_{2} \mathrm{O}_{2}$-treated coated samples at both $4 \mathrm{~h}$ and $12 \mathrm{~h}$ timepoints (Figure 5B). As previously mentioned, the superoxide radicals that are formed during the catalytic decomposition of $\mathrm{H}_{2} \mathrm{O}_{2}$ may stabilise on the anatase-coated $\mathrm{TiO}_{2}$ surface and act as an oxidative layer with antibacterial properties. Similar results have been reported by Tengvall et al. who have shown bactericidal activity against $E$. coli for superoxide radicals bound into a TiOOH matrix. ${ }^{51}$ Further, similar effects have been observed against $S$. epidermidis and $S$. mutans for $\mathrm{H}_{2} \mathrm{O}_{2}$-oxidised and $\mathrm{H}_{2} \mathrm{O}$ aged titanium, ${ }^{55}$ and against five strains related to implant-related infections for $\mathrm{TiO}_{2}$ nanocomposites following UV-irradiation. ${ }^{25}$ All these groups related the antibacterial effect to the presence of $\mathrm{O}_{2}^{-\bullet}$, and a ROS-mediated killing mechanism is therefore suggested as the main cause for the observed bactericidal effect. S. epidermidis is catalase- and superoxide dismutase (SOD) positive, and therefore, equipped with a powerful enzymatic defence mechanism to cope with oxidative stress from e.g. aerobic metabolism or environmental stresses. However, high levels of exogenous ROS from the oxidative surface may overwhelm this wall of defence and cause cell death by the interaction with vital bacterial components, such as oxidation of unsaturated phosphate lipids of the cell membrane. ${ }^{56}$ 


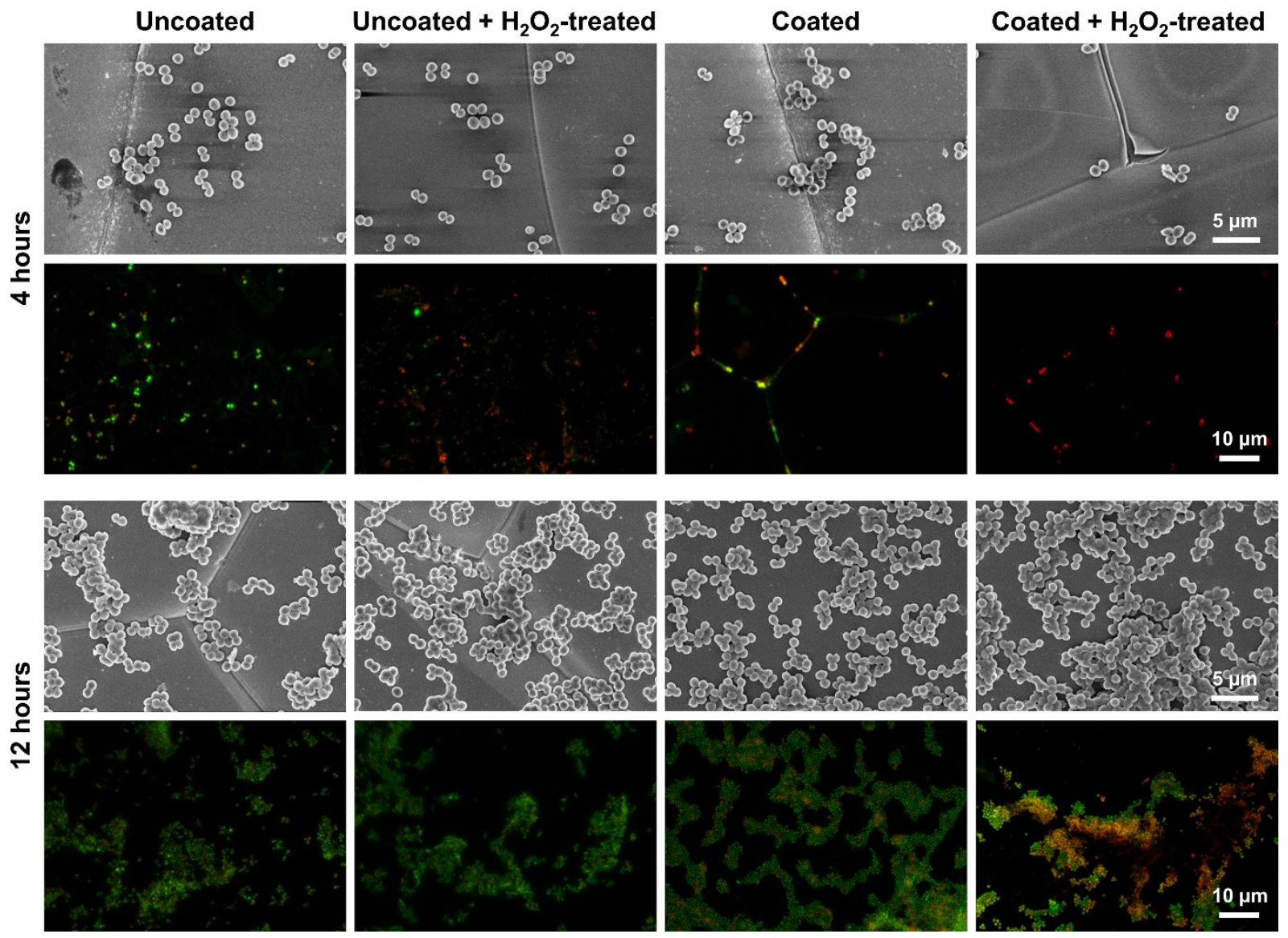

Figure 6. SEM (top row) and fluorescent microscopy images (bottom row) of S. epidermidis Xen43 biofilms on $\mathrm{TiO}_{2}$ surfaces $4 \mathrm{~h}$ and $12 \mathrm{~h}$ after seeding. Bacteria stained green are considered viable while dead bacteria are stained red.

The antibacterial activity of the coated surfaces was still observed $24 \mathrm{~h}$ after the treatment with $\mathrm{H}_{2} \mathrm{O}_{2}$ (Figures 5 and 6), and therefore, the stability of the oxidative layer in air was found to be higher than that previously reported for $\mathrm{UV}$-irradiated $\mathrm{TiO}_{2}$ surface either with or without exposure to $\mathrm{H}_{2} \mathrm{O}_{2} \cdot{ }^{25,55}$ When in contact with bacterial suspension, the stabilised radicals may be consumed and partly decompose vital bacterial compounds analogous to the degradation of MB (Figure 4). This is supported by the higher number of dead bacteria observed on the modified $\mathrm{TiO}_{2}$ surfaces $4 \mathrm{~h}$ after seeding (Figure 6). However, this is not entirely reflected by the results from the CFU assay, which shows a substantial amount of viable bacteria for the same surface (Figure 5B). One explanation for this discrepancy might be the high number of rinsing steps in the live/dead staining protocol removing loosely attached viable bacteria that have recently attached to the sample 
surface. Interestingly, adherent bacteria on the anatase-coated samples seemed to align along the grain boundaries (Figure 6). These areas are particularly prone to coating defects and thin cracks along the grain boundaries on coated $\mathrm{TiO}_{2}$ discs were observed frequently as shown in Figure 2 . Hence, these cracks may function as preferred attachment sites for bacteria and explain the overall higher number of viable bacteria on the coated samples in comparison to the uncoated surfaces (Figure 5B).

While the $\mathrm{H}_{2} \mathrm{O}_{2}$-treated anatase surfaces showed bactericidal activity after $4 \mathrm{~h}$ incubation time, they were unable to prevent biofilm formation in the long term. A homogeneous biofilm of predominantly viable bacteria covered most of the sample surface for all groups $12 \mathrm{~h}$ after seeding (Figure 6). This lack of long-term antibacterial activity may be caused by the consumption of the ROS adsorbed on the $\mathrm{H}_{2} \mathrm{O}_{2}$-exposed surfaces over time, and therefore, the formation of a less hostile environment for viable planktonic bacteria to adhere onto the surface. The secretion of EPS during biofilm maturation may further provide a physical barrier, which protects bacteria from direct contact with the oxidative layer. Nevertheless, confocal microscopy revealed patches of high toxicity against $S$. epidermidis even after $12 \mathrm{~h}$ of incubation on the $\mathrm{H}_{2} \mathrm{O}_{2}$-treated coatings (Figure 6), indicating some long-term effect of the surface modification.

\subsection{Cyto- and genotoxicity}

An antibacterial surface modification strategy based on ROS formation on $\mathrm{TiO}_{2}$ surfaces poses the risk of causing unwanted damage to tissue cells. Adverse effects of the surface modification were assessed for the murine osteoblast precursor cell line MC3T3, which has been used previously for toxicity screenings of $\mathrm{TiO}_{2}$ bone scaffolds. ${ }^{22}$ No obvious signs of cytotoxicity were observed for the osteogenic MC3T3 cells, which showed strong spreading on all tested surfaces after $24 \mathrm{~h}$ of culture (Figure 7). The observed healthy cell morphology implies that the oxidative layer on the $\mathrm{H}_{2} \mathrm{O}_{2}$-treated anatase coatings on the $\mathrm{TiO}_{2}$ surfaces caused no major damage to the cell membrane of eukaryotic cells. Further, none of the tested surfaces showed significant increase in LDH activity after $24 \mathrm{~h}$ cell culture and no significant differences in cytotoxicity were observed between either the coated and uncoated or the $\mathrm{H}_{2} \mathrm{O}_{2}$-treated and untreated $\mathrm{TiO}_{2}$ surface (Figure 8A), indicating no loss of membrane integrity for any of the tested surfaces. 

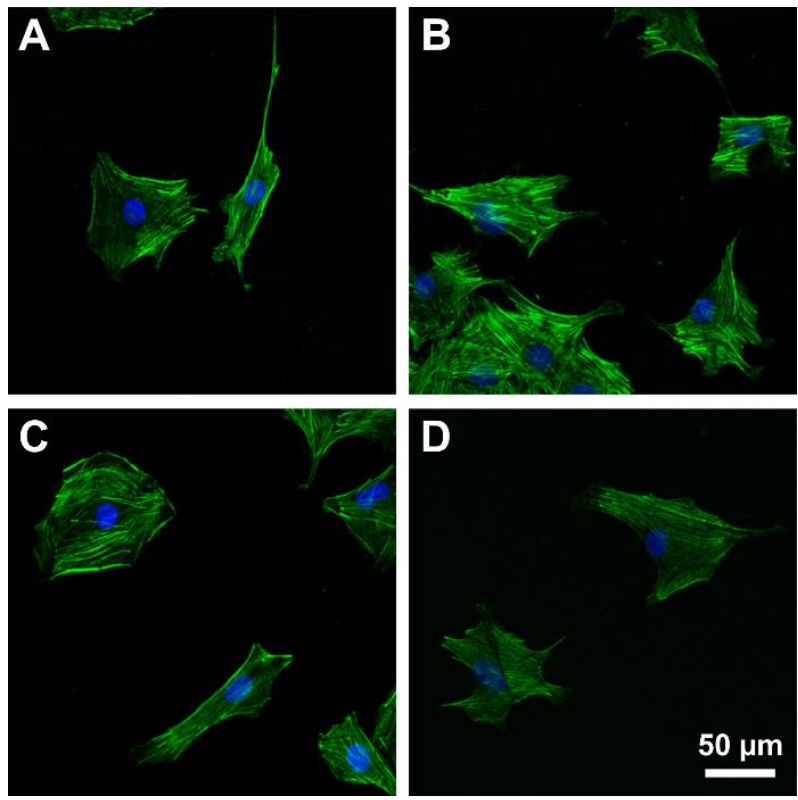

Figure 7. Morphology of adherent MC3T3 cells after culturing on (A) uncoated, (B) uncoated + $\mathrm{H}_{2} \mathrm{O}_{2}$-treated, (C) coated, (D) coated $+\mathrm{H}_{2} \mathrm{O}_{2}$-treated $\mathrm{TiO}_{2}$ surfaces for $24 \mathrm{~h}$. DAPI-stained cell nucleus shown in blue, phalloidin-stained actin filaments in green.
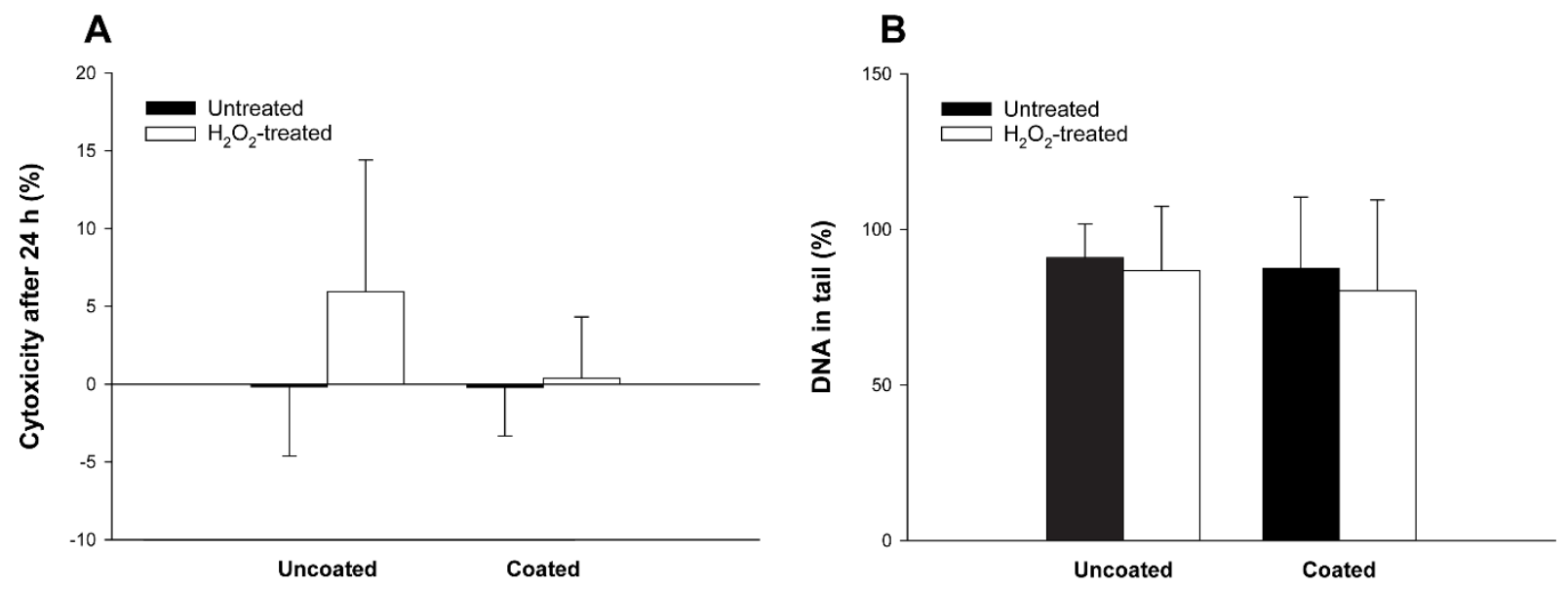

Figure 8. (A) Cytotoxicity measured as LDH activity and (B) genotoxicity evaluation based on DNA damage quantified by comet assay after culturing MC3T3 cells on the directly on the modified $\mathrm{TiO}_{2}$ surfaces for $24 \mathrm{~h}$ (mean $\pm \mathrm{SD}, n=4$ and $n=3 \times 100$ for LDH and comet assay, respectively). While no cyto- or genotoxic effects were observed for any of the sample groups, the high baseline DNA damage detected for all tested groups may mask potential ROS-mediated DNA damage in the test groups. 
The potential toxic effects of oxidative $\mathrm{TiO}_{2}$ surfaces are likely to occur predominantly due to extracellular cell damage, such as lipid peroxidation. The $\mathrm{O}_{2}^{-\bullet}$ radicals, which are formed during the interaction of $\mathrm{H}_{2} \mathrm{O}_{2}$ and $\mathrm{TiO}_{2}$ and create the oxidative layer on the metal oxide surface, ${ }^{26,30}$ are unable to cross cell membranes, thereby, suggesting extracellular damage as the most likely damaging mechanism of oxidative $\mathrm{TiO}_{2}$ surfaces. ${ }^{57}$ The absence of any detectable membranerelated damage observed on the MC3T3s may be based on a higher tolerance of MC3T3s against lipid peroxidation compared to S. epidermidis. However, intracellular ROS damage may nonetheless still occur in both mammalian and bacterial cells exposed to the oxidative layer on the modified $\mathrm{TiO}_{2}$ surfaces. It is possible that uncharged reactive species such as $\mathrm{H}_{2} \mathrm{O}_{2}$ are formed by secondary reactions of $\mathrm{O}_{2}^{-\bullet}$. $\mathrm{H}_{2} \mathrm{O}_{2}$ has been shown to cause severe DNA damage in various cells by intracellular Fenton chemistry. ${ }^{57}$ Therefore, the genotoxicity of modified $\mathrm{TiO}_{2}$ surfaces was further analysed by means of a comet assay. While the results of the comet assay showed no increase in DNA damage of $\mathrm{TiO}_{2}$ surfaces after the pre-treatment with $\mathrm{H}_{2} \mathrm{O}_{2}$ (Figure 8B), high baseline genotoxicity values were observed for all tested groups, including the unmodified $\mathrm{TiO}_{2} \mathrm{surface}$ This may be related to the poor automatic shape detection of the used analysis software for small comets or unwanted DNA damage during sample preparation. ${ }^{58}$ Further, a high overall damage of $\mathrm{TiO}_{2}$ surfaces was not supported by the cytotoxicity assay, and therefore, further studies are needed to verify the absence of irreparable DNA damage in osteogenic cells exposed to the bactericidal $\mathrm{H}_{2} \mathrm{O}_{2}$-treated $\mathrm{TiO}_{2}$ surfaces.

\section{Conclusions}

In summary, this study showed the successful application of an oxidative thin-film coating for porous ceramic scaffolds based on the dark catalytic effect of $\mathrm{TiO}_{2}$. Sol-gel derived anatase coating was observed to exhibit strong oxidative behaviour in the presence of $3 \% \mathrm{H}_{2} \mathrm{O}_{2}$, and the coating maintained some of its oxidative characteristic in the absence of an oxidative agent when preexposed to $30 \% \mathrm{H}_{2} \mathrm{O}_{2}$. While the oxidative behaviour of the anatase-coated surfaces was related to the decomposition of $\mathrm{H}_{2} \mathrm{O}_{2}$ at catalytically active sites on the sample surface and subsequent adsorption of the formed $\mathrm{O}_{2}^{-\bullet}$ on the $\mathrm{TiO}_{2}$ surface, the presence and identity of these radical species on these surfaces is yet to be shown. Thus, a thorough characterisation of the chemical surface properties of the oxidative anatase film is required to gain a better understanding of the molecular mechanism behind $\mathrm{TiO}_{2}$ dark catalysis and to identify the crucial material properties responsible 
for the high catalytic activity of the sol-gel derived anatase coatings. The oxidative $\mathrm{H}_{2} \mathrm{O}_{2}$-treated sol-gel coated surfaces showed no cytotoxic effects on MC3T3s but revealed antibacterial activity particularly at the early stages of S. epidermidis biofilm development. Further, no increase in genotoxicity was observed, and therefore, the applied surface modification provides a novel and simple strategy to functionalise $\mathrm{TiO}_{2}$ surfaces for antibacterial activity.

\section{Acknowledgments}

This study was supported by Eureka-Eurostars Project (Application E!8320 NuGel) and the Norwegian Research Council (Grant 257569). The authors acknowledge Dr Manuel Gomez-Florit, Jonas Wengenroth, and Prof. Ola Nilsen for their technical assistance with the cell study, optical profilometry, and XRD and ellipsometry.

The authors declare no competing financial interest.

\section{References}

(1) Cancedda, R.; Dozin, B.; Giannoni, P.; Quarto, R. Tissue Engineering and Cell Therapy of Cartilage and Bone. Matrix Biol. 2003, 22 (1), 81-91.

(2) Hutmacher, D. W. Scaffolds in Tissue Engineering Bone and Cartilage. Biomaterials 2000, 21 (24), 2529-2543.

(3) Eniwumide, J. O.; Yuan, H.; Cartmell, S. H.; Meijer, G. J.; de Bruijn, J. D. Ectopic Bone Formation in Bone Marrow Stem Cell Seeded Calcium Phosphate Scaffolds as Compared to Autograft and (Cell Seeded) Allograft. Eur. Cell. Mater. 2007, 14, 30-39.

(4) Miguel, B. S.; Kriauciunas, R.; Tosatti, S.; Ehrbar, M.; Ghayor, C.; Textor, M.; Weber, F. E. Enhanced Osteoblastic Activity and Bone Regeneration Using Surface-Modified Porous Bioactive Glass Scaffolds. J. Biomed. Mater. Res. Part A 2010, 94A (4), 1023-1033.

(5) Tiainen, H.; Wohlfahrt, J. C.; Verket, A.; Lyngstadaas, S. P.; Haugen, H. J. Bone Formation in $\mathrm{TiO}_{2}$ Bone Scaffolds in Extraction Sockets of Minipigs. Acta Biomater. 2012, 8 (6), 23842391.

(6) Busscher, H. J.; van der Mei, H. C.; Subbiahdoss, G.; Jutte, P. C.; van den Dungen, J. J. A. M.; Zaat, S. A. J.; Schultz, M. J.; Grainger, D. W. Biomaterial-Associated Infection: Locating the Finish Line in the Race for the Surface. Sci. Transl. Med. 2012, 4 (153), 153 rv10.

(7) Campoccia, D.; Montanaro, L.; Arciola, C. R. The Significance of Infection Related to Orthopedic Devices and Issues of Antibiotic Resistance. Biomaterials 2006, 27 (11), 2331-2339. (8) Urban, J. A.; Garvin, K. L. Prosthetic Joint Infection. Curr. Treat. Options Infect. Dis. 2003, $5,309-321$.

(9) Costerton, J. W.; Montanaro, L.; Arciola, C. R. Biofilm in Implant Infections: Its Production and Regulation. Int. J. Artif. Organs 2005, 28 (11), 1062-1068. 
(10) Corbin, A.; Pitts, B.; Parker, A.; Stewart, P. S. Antimicrobial Penetration and Efficacy in an in Vitro Oral Biofilm Model. Antimicrob. Agents Chemother. 2011, 10.1128/aac.00206-11.

(11) Campoccia, D.; Montanaro, L.; Arciola, C. R. A Review of the Biomaterials Technologies for Infection-Resistant Surfaces. Biomaterials 2013, 34 (34), 8533-8554.

(12) Banerjee, I.; Pangule, R. C.; Kane, R. S. Antifouling Coatings: Recent Developments in the Design of Surfaces That Prevent Fouling by Proteins, Bacteria, and Marine Organisms. Adv. Mater. 2011, 23 (6), 690-718.

(13) Nejadnik, M. R.; van der Mei, H. C.; Norde, W.; Busscher, H. J. Bacterial Adhesion and Growth on a Polymer Brush-Coating. Biomaterials 2008, 29 (30), 4117-4121.

(14) Jia, Z.; Xiu, P.; Xiong, P.; Zhou, W.; Cheng, Y.; Wei, S.; Zheng, Y.; Xi, T.; Cai, H.; Liu, Z.; Wang, C.; Zhang, W.; Li, Z. Additively Manufactured Macroporous Titanium with SilverReleasing Micro-/Nanoporous Surface for Multipurpose Infection Control and Bone Repair - a Proof of Concept. ACS Appl. Mater. Inter. 2016, 8 (42), 28495-28510.

(15) Wu, P.; Grainger, D. W. Drug/Device Combinations for Local Drug Therapies and Infection Prophylaxis. Biomaterials 2006, 27 (11), 2450-2467.

(16) Costa, F.; Carvalho, I. F.; Montelaro, R. C.; Gomes, P.; Martins, M. C. L. Covalent Immobilization of Antimicrobial Peptides (Amps) onto Biomaterial Surfaces. Acta Biomater. 2011, 7 (4), 1431-1440.

(17) Subbiahdoss, G.; Kuijer, R.; Grijpma, D. W.; van der Mei, H. C.; Busscher, H. J. Microbial Biofilm Growth Vs. Tissue Integration: "The Race for the Surface" Experimentally Studied. Acta Biomater. 2009, 5 (5), 1399-1404.

(18) Albers, C. E.; Hofstetter, W.; Siebenrock, K. A.; Landmann, R.; Klenke, F. M. In Vitro Cytotoxicity of Silver Nanoparticles on Osteoblasts and Osteoclasts at Antibacterial Concentrations. Nanotoxicology 2013, 7 (1), 30-36.

(19) Campoccia, D.; Montanaro, L.; Speziale, P.; Arciola, C. R. Antibiotic-Loaded Biomaterials and the Risks for the Spread of Antibiotic Resistance Following Their Prophylactic and Therapeutic Clinical Use. Biomaterials 2010, 31 (25), 6363-6377. (20) Tsukimura, N.; Kojima, N.; Kubo, K.; Att, W.; Takeuchi, K.; Kameyama, Y.; Maeda, H.; Ogawa, T. The Effect of Superficial Chemistry of Titanium on Osteoblastic Function. J. Biomed. Mater. Res. Part A 2008, 84A (1), 108-116.

(21) Tiainen, H.; Wiedmer, D.; Haugen, H. J. Processing of Highly Porous $\mathrm{TiO}_{2}$ Bone Scaffolds with Improved Compressive Strength. J. Eur. Ceram. Soc. 2013, 33 (1), 15-24.

(22) Tiainen, H.; Monjo, M.; Knychala, J.; Nilsen, O.; Lyngstadaas, S. P.; Ellingsen, J. E.; Haugen, H. J. The Effect of Fluoride Surface Modification of Ceramic $\mathrm{TiO}_{2}$ on the Surface Properties and Biological Response of Osteoblastic Cells in Vitro. Biomed. Mater. 2011, 6 (4), 045006.

(23) Visai, L.; De Nardo, L.; Punta, C.; Melone, L.; Cigada, A.; Imbriani, M.; Arciola, C. R. Titanium Oxide Antibacterial Surfaces in Biomedical Devices. Int. J. Artif. Organs 2011, 34 (9), 929.

(24) Hashimoto, K.; Irie, H.; Fujishima, A. TiO 2 Photocatalysis: A Historical Overview and Future Prospects. Jpn. J. Appl. Phys. 2005, 44 (12R), 8269.

(25) Cai, Y.; Strømme, M.; Welch, K. Photocatalytic Antibacterial Effects Are Maintained on Resin-Based $\mathrm{TiO}_{2}$ Nanocomposites after Cessation of UV Irradiation. PLOS ONE 2013, 8 (10), e75929.

(26) Wiedmer, D.; Sagstuen, E.; Welch, K.; Haugen, H. J.; Tiainen, H. Oxidative Power of Aqueous Non-Irradiated $\mathrm{TiO}_{2}-\mathrm{H}_{2} \mathrm{O}_{2}$ Suspensions: Methylene Blue Degradation and the Role of Reactive Oxygen Species. Appl. Catal. B 2016, 198, 9-15. 
(27) Sánchez, L. D.; Taxt-Lamolle, S. F. M.; Hole, E. O.; Krivokapić, A.; Sagstuen, E.; Haugen, H. J. $\mathrm{TiO}_{2}$ Suspension Exposed to $\mathrm{H}_{2} \mathrm{O}_{2}$ in Ambient Light or Darkness: Degradation of Methylene Blue and EPR Evidence for Radical Oxygen Species. Appl. Catal. B 2013, 142-143 (0), 662-667.

(28) Gustumhaugen, E.; Lönn-Stensrud, J.; Scheie, A. A.; Lyngstadaas, S. P.; Ekfeldt, A.; TaxtLamolle, S. Effect of Chemical and Mechanical Debridement Techniques on Bacterial ReGrowth on Rough Titanium Surfaces: An in Vitro Study. Clin. Oral Implants Res. 2014, 25 (6), 707-713.

(29) Henderson, E.; Schneider, S.; Petersen, F. C.; Haugen, H. J.; Wohlfahrt, J. C.; Ekstrand, K.; Ekfeldt, A. Chemical Debridement of Contaminated Titanium Surfaces: An in Vitro Study. Acta Odontol. Scand. 2013, 71 (3-4), 957-964.

(30) Anpo, M.; Che, M.; Fubini, B.; Garrone, E.; Giamello, E.; Paganini, M. C. Generation of Superoxide Ions at Oxide Surfaces. Top. Catal. 1999, 8 (3), 189.

(31) Tengvall, P.; Lundström, I.; Sjöqvist, L.; Elwing, H.; Bjursten, L. M. Titanium-Hydrogen Peroxide Interaction: Model Studies of the Influence of the Inflammatory Response on Titanium Implants. Biomaterials 1989, 10 (3), 166-175.

(32) Tiainen, H.; Lyngstadaas, S. P.; Ellingsen, J. E.; Haugen, H. J. Ultra-Porous Titanium Oxide Scaffold with High Compressive Strength. J. Mater. Sci.: Mater. Med. 2010, 21 (10), 2783-2792. (33) Verket, A.; Tiainen, H.; Haugen, H. J.; Lyngstadaas, S. P.; Nilsen, O.; Reseland, J. E. Enhanced Osteoblast Differentiation on Scaffolds Coated with $\mathrm{TiO}_{2}$ Compared to $\mathrm{SiO}_{2}$ and $\mathrm{CaP}$ Coatings. Biointerphases 2012, 10.1007/s13758-012-0036-8.

(34) Müller, B.; Haugen, H.; Nilsen, O.; Tiainen, H. Atomic Layer Deposited $\mathrm{TiO}_{2}$ Protects Porous Ceramic Foams from Grain Boundary Corrosion. Corrosion Science 2016, 106, 35-42. (35) Vuong, C.; Kocianova, S.; Yu, J.; Kadurugamuwa, J. L.; Otto, M. Development of RealTime in Vivo Imaging of Device-Related Staphylococcus epidermidis Infection in Mice and Influence of Animal Immune Status on Susceptibility to Infection. J. Infect. Dis. 2008, 198 (2), 258-261.

(36) Wiedmer, D.; Petersen, F. C.; Lönn-Stensrud, J.; Tiainen, H. Antibacterial Effect of Hydrogen Peroxide-Titanium Dioxide Suspensions in the Decontamination of Rough Titanium Surfaces. Biofouling 2017, 33 (6), 451-459.

(37) Kueper, T. W.; Visco, S. J.; De Jonghe, L. C. Thin-Film Ceramic Electrolytes Deposited on Porous and Non-Porous Substrates by Sol-Gel Techniques. Solid State Ion. 1992, 52 (1), 251259.

(38) Langlet, M.; Permpoon, S.; Riassetto, D.; Berthomé, G.; Pernot, E.; Joud, J. C.

Photocatalytic Activity and Photo-Induced Superhydrophilicity of Sol-Gel Derived $\mathrm{TiO}_{2}$ Films. J. Photoch. Photobio. A 2006, 181 (2), 203-214.

(39) Simonsen, M. E.; Li, Z.; Søgaard, E. G. Influence of the Oh Groups on the Photocatalytic Activity and Photoinduced Hydrophilicity of Microwave Assisted Sol-Gel $\mathrm{TiO}_{2}$ Film. Appl. Surf. Sci. 2009, 255 (18), 8054-8062.

(40) Ohya, Y.; Mishina, J.; Matsuda, T.; Ban, T.; Takahashi, Y. Crystallization and Microstructure Development of Sol-Gel-Derived Titanium Dioxide Thin Films with Single and Multiple Layers. J. Am. Ceram. Soc. 1999, 82 (10), 2601-2606.

(41) Takahashi, Y.; Matsuoka, Y. Dip-Coating of Tio 2 Films Using a Sol Derived from Ti(O-IPr) 4 -Diethanolamine- $\mathrm{H}_{2} \mathrm{O}-\mathrm{I}$-PrOH System. J. Mater. Sci. 1988, 23 (6), 2259-2266.

(42) Yu, J.; Zhao, X.; Zhao, Q. Effect of Film Thickness on the Grain Size and Photocatalytic Activity of the Sol-Gel Derived Nanometer $\mathrm{TiO}_{2}$ Thin Films. J. Mater. Sci. Lett. 2000, 19 (12), 1015-1017. 
(43) Hiroki, A.; LaVerne, J. A. Decomposition of Hydrogen Peroxide at Water-Ceramic Oxide Interfaces. J. Phys. Chem. B 2005, 109 (8), 3364-3370.

(44) Lousada, C. M.; Johansson, A. J.; Brinck, T.; Jonsson, M. Mechanism of $\mathrm{H}_{2} \mathrm{O}_{2}$

Decomposition on Transition Metal Oxide Surfaces. J. Phys. Chem. C 2012, 116 (17), 95339543.

(45) Lousada, C. M.; Yang, M.; Nilsson, K.; Jonsson, M. Catalytic Decomposition of Hydrogen Peroxide on Transition Metal and Lanthanide Oxides. J. Mol. Catal. A: Chem. 2013, 379, 178184.

(46) George, S. M. Atomic Layer Deposition: An Overview. Chem. Rev. 2010, 110 (1), 111-131. (47) Prusakova, V.; Armellini, C.; Carpentiero, A.; Chiappini, A.; Collini, C.; Dirè, S.; Ferrari, M.; Lorenzelli, L.; Nardello, M.; Normani, S.; Vaccari, A.; Chiasera, A. Morphologic, Structural, and Optical Characterization of Sol-Gel Derived $\mathrm{TiO}_{2}$ Thin Films for Memristive Devices. Phys. Status Solidi C 2015, 12 (1-2), 192-196.

(48) Antcliff, K. L.; Murphy, D. M.; Griffiths, E.; Giamello, E. The Interaction of $\mathrm{H}_{2} \mathrm{O}_{2}$ with Exchanged Titanium Oxide Systems (TS-1, TiO 2 , [Ti]-APO-5, Ti-ZSM-5). Phys. Chem. Chem. Phys. 2003, 5 (19), 4306-4316.

(49) Tengvall, P.; Wälivaara, B.; Westerling, J.; Lundström, I. Stable Titanium Superoxide Radicals in Aqueous Ti-Peroxy Gels and Ti-Peroxide Solutions. J. Colloid Interface Sci. 1991, 143 (2), 589-592.

(50) Larsson, J.; Persson, C.; Tengvall, P.; Lundqvist-Gustafsson, H. Anti-Inflammatory Effects of a Titanium-Peroxy Gel: Role of Oxygen Metabolites and Apoptosis. J. Biomed. Mater. Res.

Part A 2004, 68A (3), 448-457.

(51) Tengvall, P.; Hörnsten, E. G.; Elwing, H.; Lundström, I. Bactericidal Properties of a Titanium-Peroxy Gel Obtained from Metallic Titanium and Hydrogen Peroxide. J. Biomed. Mater. Res. 1990, 24 (3), 319-330.

(52) Otto, M. Staphylococcal Biofilms. In Bacterial Biofilms; Romeo, T., Ed.; Springer: Berlin Heidelberg, 2008; pp 207-228.

(53) Otto, M. Staphylococcus epidermidis - the 'Accidental' Pathogen. Nat. Rev. Microbiol. 2009, $7(8), 555-567$.

(54) Mack, D.; Davies, A. P.; Harris, L. G.; Jeeves, R.; Pascoe, B.; Knobloch, J. K.-M.; Rohde, H.; Wilkinson, T. S. Staphylococcus epidermidis in Biomaterial-Associated Infections. In Biomaterials Associated Infection: Immunological Aspects and Antimicrobial Strategies; Moriarty, T. F.; Zaat, S. A. J.; Busscher, H. J., Eds.; Springer New York: New York, NY, 2013; pp 25-56.

(55) Unosson, E.; Tsekoura, E. K.; Engqvist, H.; Welch, K. Synergetic Inactivation of Staphylococcus epidermidis and Streptococcus mutans in a $\mathrm{TiO}_{2} / \mathrm{H}_{2} \mathrm{O}_{2} / \mathrm{UV}$ System. Biomatter 2013, 3 (4), e26727.

(56) Kiwi, J.; Nadtochenko, V. New Evidence for $\mathrm{TiO}_{2}$ Photocatalysis During Bilayer Lipid Peroxidation. J. Phys. Chem. B 2004, 108 (45), 17675-17684.

(57) Halliwell, B.; Gutteridge, J. M. C. Oxidative Stress and Redox Regulation: Damage, Repair, Senescence, and Death. In Free Radicals in Biology and Medicine; Oxford University Press: USA, 2015; pp 199-283.

(58) Speit, G.; Kojima, H.; Burlinson, B.; Collins, A. R.; Kasper, P.; Plappert-Helbig, U.; Uno, Y.; Vasquez, M.; Beevers, C.; De Boeck, M.; Escobar, P. A.; Kitamoto, S.; Pant, K.; Pfuhler, S.; Tanaka, J.; Levy, D. D. Critical Issues with the in Vivo Comet Assay: A Report of the Comet Assay Working Group in the 6th International Workshop on Genotoxicity Testing (IWGT). Mutat. Res. Genet. Toxicol. Environ. Mutagen. 2015, 783, 6-12. 